\title{
EFFECT OF CLIMATE CHANGE ON THE DEMOGRAPHICS OF CURITIBA PRISMATICA (D. LEGRAND) SALYWON \& LANDRUM: AN ENDEMIC ARAUCARIA FOREST SPECIES
}

\author{
Richeliel Albert Rodrigues Silva ${ }^{1 *}$, Luciano Farinha Watzlawick², Henrique Soares Koehler ${ }^{3}$, Fábio de \\ Almeida Vieira ${ }^{4}$, Fernanda Moura Fonseca Lucas ${ }^{5}$, Kyvia Pontes Teixeira das Chagas ${ }^{6}$ \\ 1* Universidade Estadual do Centro-Oeste, Irati, Paraná, Brasil - richeliel@ yahoo.com.br* \\ ${ }^{2}$ Universidade Estadual do Centro-Oeste, Irati, Paraná, Brasil - farinha@ unicentro.br \\ ${ }^{3}$ Universidade Federal do Paraná, Curitiba, Paraná, Brasil - koehler@ufpr.br \\ ${ }^{4}$ Universidade Federal do Rio Grande do Norte, Macaíba, Rio Grande do Norte, Brasil - vieirafa@ gmail.com \\ ${ }^{5}$ Universidade Federal do Espírito Santo, Jerônimo Monteiro, Espírito Santo, Brasil - fernanda-fonseca@ hotmail.com \\ ${ }^{6}$ Universidade Federal do Paraná, Curitiba, Paraná, Brasil - kyviapontes@gmail.com \\ Received for publication: 24/06/2020 - Accepted for publication: 12/11/2020
}

\begin{abstract}
Resumo
Efeito da mudança climática na demografia de Curitiba prismatica (D. Legrand) Salywon \& Landrum: uma espécie endêmica da Floresta com Araucária. Com a ocorrência da intensiva mudança climática, há o risco de ocorrerem danos irreversíveis à biodiversidade global, podendo resultar na redução da distribuição geográfica e extinção de espécies. Diante disso, objetivou-se avaliar a distribuição atual e a projeção futura das áreas de ocorrência de Curitiba prismatica. Foram coletados dados de ocorrência atual acessados na base de dados SpeciesLink e em trabalhos científicos, que foram correlacionados com os dados bioclimáticos disponíveis no WorldClim, para os períodos atual e futuro (2070), nos cenários otimista (RCP 4.5) e pessimista (RCP 8.5) do modelo HadGEM2-ES. No cenário atual, a espécie apresenta adequabilidade restrita à Floresta Ombrófila Mista (FOM), com distribuição limitada ao Centro-Sul do Paraná e ao Norte de Santa Catarina. Para o futuro ocorreram reduções nas áreas de suscetibilidade climática para a espécie, tanto no cenário otimista, quanto pessimista. No cenário RCP 4.5, a redução preditiva foi significativa na região do Centro-Oeste do Paraná, diferentemente do cenário RCP 8.5, que apresentou baixa redução nesta região. Portanto, no futuro, as áreas com elevada adequabilidade tendem a ficarem reduzidas, no entanto, restritas às regiões do primeiro e segundo planalto paranaense e Norte do estado de Santa Catarina. Neste sentido, estas áreas são indicadas para plantio comercial e conservação in situ e ex situ da espécie.

Palavras-chave: adequabilidade, conservação, manejo florestal, Myrtaceae
\end{abstract}

\section{Abstract}

With the occurrence of intensive climate change, there is a risk of irreversible damage to global biodiversity, resulting in reduction of geographical distribution and species extinction. The objective of this study was to evaluate the current distribution and the future projection of the areas of occurrence of Curitiba prismatica. Current occurrence data accessed in the SpeciesLink database and scientific studies were collected, which were correlated with the bioclimatic data available in WorldClim, for the current and future periods (2070), in the optimistic (RCP 4.5) and pessimistic scenarios (RCP 8.5) of the HadGEM2-ES model. In the current scenario, a species presents suitability restricted to mixed ombrophilous forest (MOF), with limited distribution to the center-south of the state of Paraná and the north of the state of Santa Catarina. For the future, there were reductions in the areas of climatic susceptibility for the species, both in the optimistic and pessimistic scenarios. In the RCP 4.5 scenario, the predictive reduction was found in the midwest region of Paraná, unlike the RCP 8.5 scenario, which showed a low reduction in this region. Therefore, in the future, areas with high suitability will tend to contract, but restricted to the regions of the first and second plateau of Parana and the north of Santa Catarina. In this sense, these areas are indicated for commercial planting and in situ and ex situ conservation of the species.

Keywords: suitability, conservation, forest management, Myrtaceae

\section{INTRODUCTION}

The Atlantic Forest Biome contains an impressive richness of species and is considered a hotspot for the conservation of biodiversity, to conserve and maintain natural resources and typical communities. The mixed ombrophilous forest (MOF) is a phytophysiognomy of the Atlantic Forest, whose main characteristic is the presence of Araucaria angustifolia (Bertol.) Kuntze. MOF occurs mainly in the states of Paraná, Santa Catarina and Rio Grande do Sul, with scattered patches in high altitude regions of São Paulo, Minas Gerais, and Rio de Janeiro (IBGE, 2012). Currently, it is estimated that the area covered with the MOF has been reduced to only $12.3 \%$ of its original coverage (RIBEIRO et al., 2009).

One of the native and endemic species of MOF is Curitiba prismatica (D. Legrand) Salywon \& Landrum (FLORA DO BRASIL, 2020), popularly known as murta, guamirim or cambuí (LORENZI, 2014). The species 
belongs to the Myrtaceae family, considered one of the largest botanical families, comprising 6,141 taxa in the world and 1,033 in Brazil, with 795 endemic species (THE PLANT LIST, 2013; FLORA DO BRASIL, 2020). Curitiba prismatica occurs in the area that covers the states of Paraná and Santa Catarina (FLORA DO BRASIL, 2020).

With the significant reduction of the areas occupied by native MOF species, studies of ecological niches are indispensable. According to Hutchinson (1957), a species can occur when the necessary resources and environmental conditions are appropriate for its establishment. Thus, global climate change can influence taxonomic homogenization in the remaining Atlantic Forest fragments, due to changes in the niches and geographic distribution of species (ZWIENER et al., 2017).

Therefore, ecological niche models are increasingly used as a tool to predict the geographic distribution of species. Based on this information, it will be possible to indicate which bioclimatic variables contribute to the reduction or emergence of areas suitable for a species in the current and future scenarios. Thus, the most and least satisfactory places for the development of the species can be indicated. According to the IPCC (2007), the risk of extinction will increase between 20 and $30 \%$ in plant and animal species if the increase in the average global temperature exceeds 1.5 to $2.5^{\circ} \mathrm{C}$. This increase may cause some species to adapt and migrate to regions that present conditions like those in which they currently occur. Therefore, the information obtained from the analysis of the ecological niche, spatial pattern, and dynamics will serve as a strategic tool to mitigate possible damage to the future occurrence of Curitiba prismatica.

Given the above, the main objective of this study was to evaluate, through analysis of the fundamental ecological niche, the regions with greater climate adaptability for the occurrence of Curitiba prismatica for the present and future period (2070). For this, the following hypotheses were tested: 1) climate change will negatively affect areas with high suitability for the occurrence of Curitiba prismatica, and 2) new areas with high suitability will emerge in the future.

\section{MATERIAL AND METHODS}

For the construction of the predictions, points of natural occurrence combined with bioclimatic variables were used. Occurrence records of Curitiba prismatica were obtained from the SpeciesLink database (http://splink.cria.org.br/), which integrates primary data from scientific collections. Coordinates from other scientific works were also used (KOZERA et al., 2006; GREINER et al., 2011; SIMINSKI et al., 2011; WATZLAWICK et al., 2011; SAWCZUK et al., 2012; BARRETO et al., 2014).

Regarding the bioclimatic variables, 19 layers were used, obtained from the Worldclim database version 1.4 (http://www.worldclim.org/bioclim), at a resolution of $1 \mathrm{~km}$ (30 arc seconds) (Table 1). Later, the environmental layers were trimmed for Brazil, aiming to improve the prediction of the species distribution. This procedure was performed in the Quantum GIS (QGIS) v. 3.0.0 database (https://www.qgis.org/pt_BR/site/).

Table 1. Bioclimatic variables for ecological niche modeling.

Tabela 1. Variáveis bioclimáticas para modelagem de nicho ecológico.

\begin{tabular}{cc}
\hline Bioclimatic variables & Description \\
bio 1 & Annual average temperature \\
bio 2 & Average daytime temperature variation \\
bio 3 & Isothermality \\
bio 4 & Temperature seasonality \\
bio 5 & Maximum temperature of the hottest month \\
bio 6 & Minimum temperature of the coldest month \\
bio 7 & Current thermal amplitude \\
bio 8 & Average temperature of the wettest quarter \\
bio 9 & Average temperature of the driest quarter \\
bio 10 & Average temperature of the hottest quarter \\
bio 11 & Average temperature of the coldest quarter \\
bio 12 & Annual rainfall \\
bio 13 & Rainiest month precipitation \\
bio 14 & Precipitation of the driest month \\
bio 15 & Precipitation seasonality \\
bio 16 & Rainiest quarter rainfall \\
bio 17 & Precipitation of the driest quarter \\
bio 18 & Hottest quarter precipitation \\
bio 19 & Precipitation of the coldest quarter
\end{tabular}


Then, the bioclimatic variables were submitted to Pearson correlation testing (rp), with the ENMTools 1.3 software (http://purl.oclc.org/enmtools). The aim was to identify whether one or more layers had the same information, with exclusion of those that presented a positive or negative correlation above 0.85 . This was done to minimize the overfitting of the model and the multicollinearity between the variables, to favor the prediction of the models. In addition, the software was used to filter out spurious coordinates and overlapping points.

For the modeling in the current period, the average of the bioclimatic variables in the period from 1960 to 2000 was used, and for the future, the average was between 2061 and 2080. For the future (2070), predictions were made for the optimistic (RCP 4.5) and pessimistic (RCP 8.5) climate scenarios, both from the HadGEM2-ES general circulation atmospheric model. The optimistic scenario is part of an intermediate scenario, where $\mathrm{CO}_{2}$ (carbon dioxide) emissions in 2070 decline in relation to current levels, and the radiative force stabilizes at 4.5 $\mathrm{W} / \mathrm{m}^{2}$ by the end of the century. The pessimistic scenario denotes high levels of greenhouse gas emissions and energy demand, resulting in radiative forcing of $8.5 \mathrm{~W} / \mathrm{m}^{2}$ up to 2100 (representative concentration route Intergovernmental Panel on Climate Change - IPCC) (IPCC, 2007).

The ecological niche models were formulated using the MaxEnt software version $3.3 .3 \mathrm{k}$, based on the maximum entropy algorithm. The parameters used in the model were a convergence threshold of $10^{-5}, 5,000$ interactions, and 10,000 background points, as well as the random seed and auto features options. The contribution of each bioclimatic variable was analyzed using jackknife methods, and the respective response curves were plotted. The dataset was submitted to 10 repetitions of the model, and for each one, a bootstrap validation with replacement was performed, in which the data were divided into two independent sets to calibrate and validate the model, containing 30 and $70 \%$, respectively.

The area under the curve (AUC), used to measure the level of fit of the model, was also calculated. AUC values close to 1 indicate that the model has high accuracy in predicting the occurrence of the species, while values close to 0.5 indicate that the model has low accuracy. Then the distribution and potential suitability map of the species was constructed using the Quantum GIS (QGIS) program. Suitability is demonstrated by means of a color gradient scale, where red represents the greatest suitability and blue the least. Each pixel has a value ranging from 0 to 1 . The actual pattern of distribution of the species in the current period was also verified. For this, the occurrence data of the species were related to the following abiotic variables: average annual temperature (bio 1), annual precipitation (bio 12), and altitude, with a spatial resolution of 30 meters, according to the Worldclim and TOPODATA databases (http://www.dsr.inpe.br/topodata/).

\section{RESULTS}

After calculating the bivariate correlations between the 19 bioclimatic variables, eight were used to build the predictive models (Table 2). The variables that most contributed to the construction of the models were: bio 5 (maximum temperature in the hottest month), bio 6 (minimum temperature in the coldest month), and bio 14 (precipitation in the driest month). As for the percentage of permutation, the most relevant variable in all periods and scenarios analyzed was the minimum temperature of the coldest month.

Table 2. Bioclimatic variables used as predictors of the geographic distribution of Curitiba prismatica for the present and future scenarios (RCP 4.5 and RCP 8.5).

Tabela 2. Variáveis bioclimáticas usadas como preditoras da distribuição geográfica de Curitiba prismatica para os cenários presente e futuro (RCP 4.5 e RCP 8.5).

\begin{tabular}{|c|c|c|c|c|c|c|c|}
\hline \multirow{2}{*}{$\begin{array}{l}\text { Bioclimatic } \\
\text { variables }\end{array}$} & \multirow[t]{2}{*}{ Description } & \multicolumn{3}{|c|}{ Contribution (\%) } & \multicolumn{3}{|c|}{$\begin{array}{c}\text { Importance of } \\
\text { permutation }(\%)\end{array}$} \\
\hline & & Current & $\begin{array}{c}\text { Future } \\
(4.5)\end{array}$ & $\begin{array}{c}\text { Future } \\
(8.5)\end{array}$ & Current & $\begin{array}{c}\text { Future } \\
(4.5)\end{array}$ & $\begin{array}{c}\text { Future } \\
(8.5)\end{array}$ \\
\hline bio 3 & Isothermality & 2.3 & 11.5 & 14.2 & 0.4 & 3.3 & 5.2 \\
\hline bio 5 & $\begin{array}{l}\text { Maximum } \\
\text { temperature of the } \\
\text { hottest month }\end{array}$ & 30.4 & 23.0 & 19.0 & 4.0 & 0.3 & 0.7 \\
\hline bio 6 & $\begin{array}{l}\text { Minimum } \\
\text { temperature of the } \\
\text { coldest month }\end{array}$ & 24.2 & 23.7 & 22.8 & 23.7 & 39.8 & 52.4 \\
\hline bio 14 & $\begin{array}{l}\text { Precipitation of } \\
\text { the driest month }\end{array}$ & 35.9 & 35.1 & 39.1 & 14.4 & 3.3 & 2.4 \\
\hline
\end{tabular}




\begin{tabular}{cccccccc}
\hline bio 15 & $\begin{array}{c}\text { Precipitation } \\
\text { seasonality }\end{array}$ & 5.8 & 0.7 & 1.3 & 9.9 & 13.7 & 28.4 \\
\hline bio 16 & $\begin{array}{c}\text { Rainiest quarter } \\
\text { rainfall }\end{array}$ & 1.0 & 0.7 & 0.7 & 19.2 & 0.8 & 0.1 \\
\hline bio 18 & $\begin{array}{c}\text { Hottest quarter } \\
\text { precipitation }\end{array}$ & 0.2 & 0.2 & 0.2 & 20.1 & 1.8 & 3.0 \\
\hline bio 19 & $\begin{array}{c}\text { Coldest quarter } \\
\text { precipitation }\end{array}$ & 0.2 & 5.2 & 2.6 & 7.4 & 37.1 & 7.7 \\
\hline
\end{tabular}

According to the jackknife test, the variables bio 5 and bio 14 presented the most useful information, when used independently. The model used presented a good fit, with an AUC value of 0.997 and standard deviation of \pm 0.001 .

In the current period, Curitiba prismatica has a restricted distribution in mixed ombrophilous forest areas, with greater suitability in the center-south of Paraná and north of Santa Catarina (Figure 1A). The state of Paraná concentrates the greatest extent of suitable areas for the species in all scenarios. Despite this, in the future (2070) there were reductions in areas suitable for the species in the optimistic (RCP 4.5) and pessimistic (RCP 8.5) scenarios. Also, through these scenarios it was possible to observe the exclusion of an area of low suitability in Rio Grande do Sul, as well as the reduction of the coastal region in the state of São Paulo. In the RCP 4.5 scenario, the reduction was more significant in the midwest region of Paraná (Figure 1B), unlike the RCP 8.5 scenario, which showed low reduction in this region (Figure 1C).

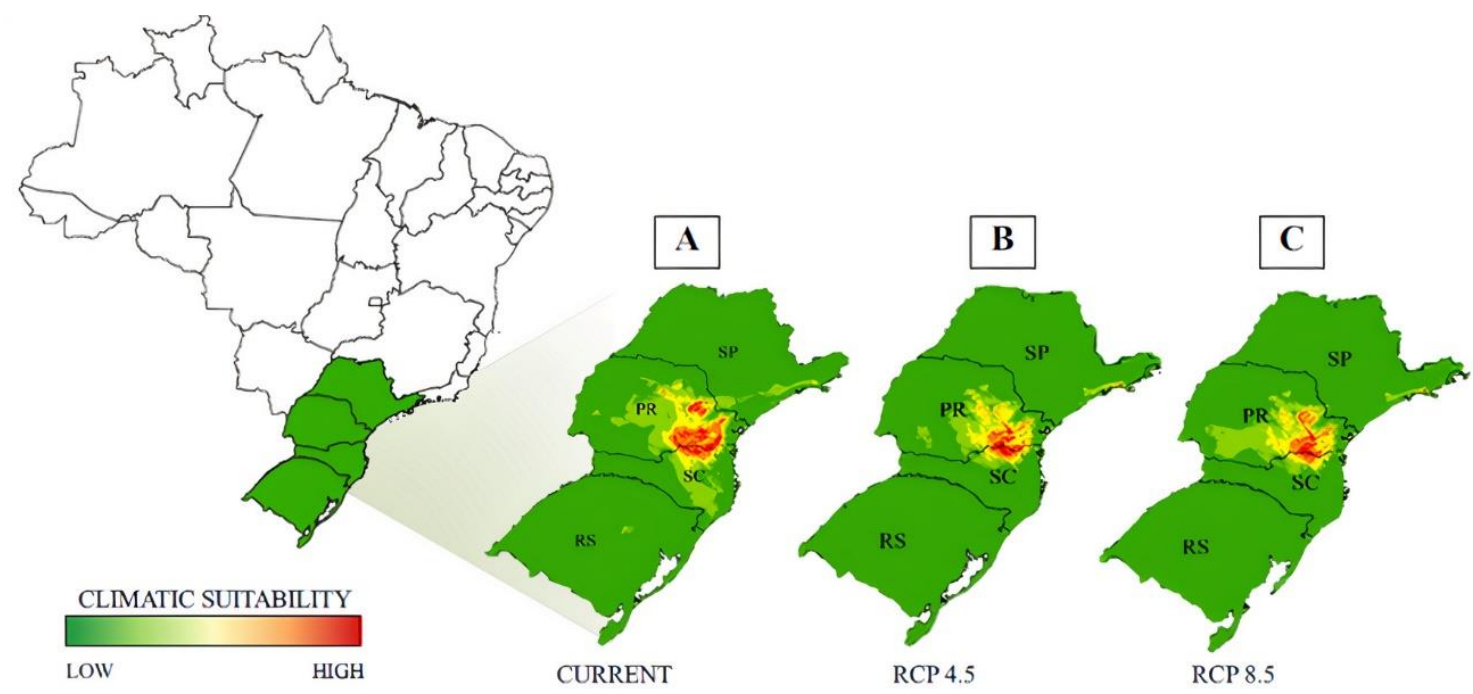

Figure 1. Distribution and suitable areas for Curitiba prismatica in the present and future periods (2070). (A) Present, (B) optimistic scenario (RCP 4.5) for 2070 and (C) pessimistic scenario (RCP 8.5) for 2070.

Figura 1. Distribuição e áreas de adequabilidade de Curitiba prismatica nos períodos presente e futuro (2070). (A) Presente, (B) cenário otimista RCP 4.5 para 2070 e (C) cenário pessimista RCP 8.5 para 2070.

According to the geographic occurrence data of Curitiba prismatica, considering the altitude, temperature and precipitation data available from the Brazilian Institute of Geography and Statistics (IBGE), the species has a tendency to occur in areas with high altitude, low temperature and moderate precipitation, which may explain its high endemism (Figure 2B, C e D). 

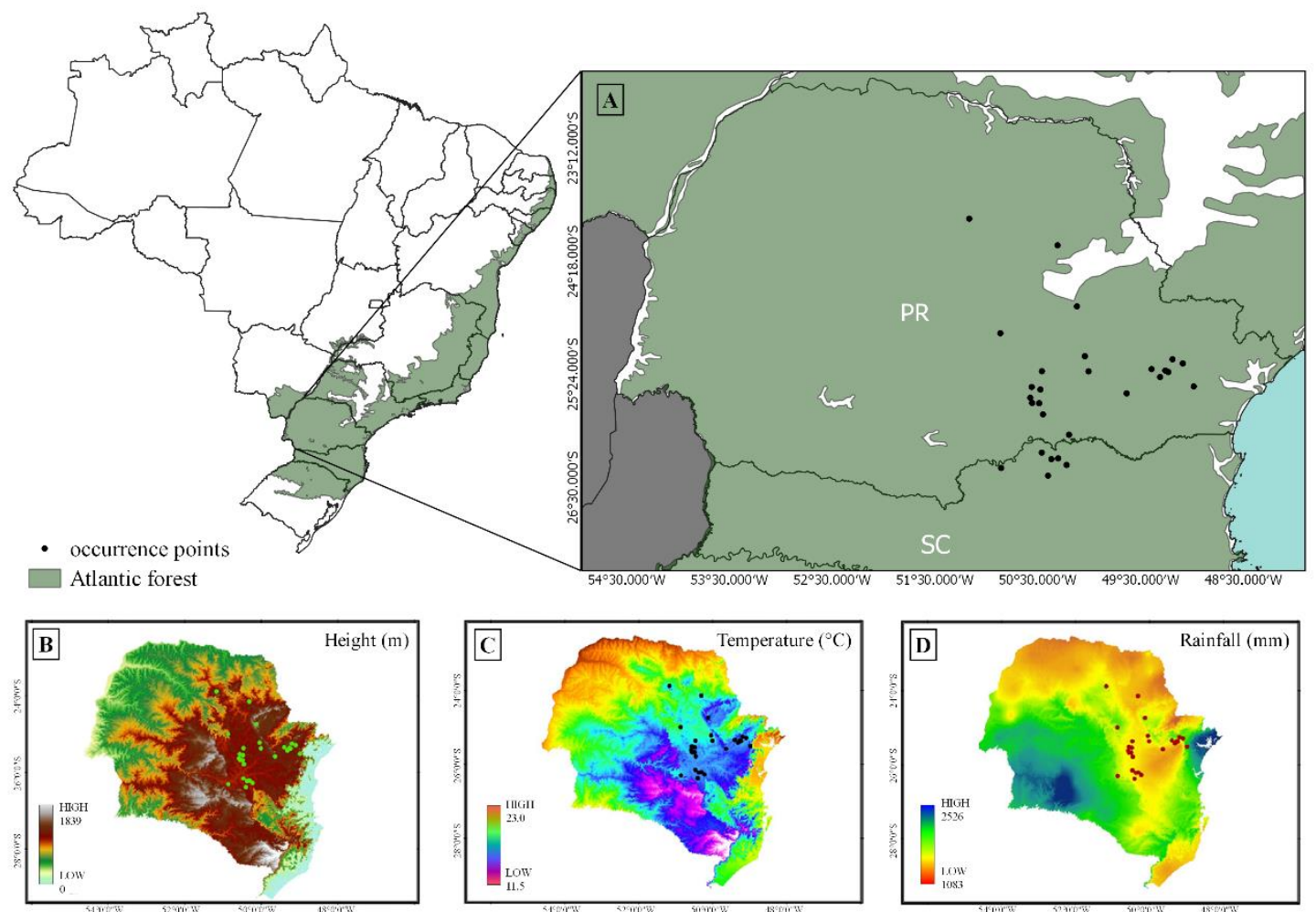

Figure 2. (A) Occurrence sites used in ecological niche modeling of Curitiba prismatica, (B) distribution according to average altitude, $(C)$ average temperature and (D) rainfall.

Figura 2. (A) Locais de ocorrência utilizados na modelagem do nicho ecológico de Curitiba prismática, (B) distribuição de acordo com altitude média, (C) temperatura média e (D) precipitação média.

\section{DISCUSSION}

The results obtained were like those observed for several other plant species from the Atlantic Forest, such as Vriesea incurvata (AGUIAR-MELO et al., 2019), Myrsine spp. (SÁNCHEZ-TAPIA et al., 2018) and Eremanthus erythropappus (CARVALHO et al., 2019). Interestingly, the species currently has strong presence in regions under forest management, such as the Faxinal and Caivas systems, which are two community production systems (Table 3). These places, located in the center-south regions of Paraná and north of Santa Catarina, have an average temperature in the warmest month below $18{ }^{\circ} \mathrm{C}$, with frequent severe frosts, without a defined dry season (IBGE, 2012), indicating that the species is well suited to low temperatures. In addition, possibly the region is the center of origin of the species, due to the high density of individuals (WATZLAWICK et al., 2011).

The precipitation of the driest month (bio14) is the variable that most influences the occurrence of the species, including in future scenarios, indicating that precipitation is very important for the suitability of the species (Table 2). As it is an endemic species of mixed ombrophilous forest areas, the low rainfall in dry periods is a limiting factor for its occurrence (Table 2). MOF is characterized by a high number of endemic species, with the presence of species from the Myrtaceae family, as is the case of Curitiba prismatica, in the lower strata (RODERJAN et al., 2002).

With the high fragmentation, which occurred with more intensity mainly in the metropolitan region of Curitiba, one of the places where the species occurs in high density, this effect probably caused significant damage to its maintenance (Figure 1). Despite fragmentation, the species has been conserved mainly in conservation units in the region of Curitiba (first plateau) and areas of sustenance extraction, such as faxinais and caivas, in the midwest of Paraná (second plateau) and north of Santa Catarina. Altitude is also probably a limiting factor for the natural dispersion of Curitiba prismatica. Since it is a species with zoochoric dispersion, animals such as birds disperse the seeds where they are located (URBANETZ et al., 2003), that is, these dispersers cannot cross geographic barriers. Thus, the species has the characteristic of a specialist, due to its restricted niche, in addition to showing a tendency towards the formation of population centers.

Regarding future projections based on climate change, Silva et al. (2018) observed a reduction in suitability in the most pessimistic scenario for Ilex paraguariensis. These results indicate that with climate change, 
the distribution areas of these species will tend to decrease. This reduction corroborates the estimates by Bergamin et al. (2019), who stated that Araucaria Forest areas will continue to be reduced under projected future climate change.

The density of individuals corroborates the projections for Curitiba prismatica, indicating that areas with high suitability have the highest densities, such as in Curitiba, faxinal area in Rebouças, PR, and caíva in Major Vieira, SC (Table 3). In these places, except in faxinal areas, the communities presented a moderate ShannonWiener diversity index. Maia et al. (2019), evaluating an Atlantic Forest fragment, observed that the plasticity of the species niche is not significantly related to the suitability and richness, but negatively to the abundance and diversity indices.

Table 3. Density and Shannon-Wiener diversity (MAGURRAN, 2011) indices in different areas of natural occurrence of Curitiba prismatica.

Tabela 3. Índices de densidade e diversidade de Shannon-Wiener (MAGURRAN, 2011) em diferentes áreas de ocorrência natural de Curitiba prismatica.

\begin{tabular}{|c|c|c|c|c|}
\hline Sites & $\begin{array}{c}\text { Density } \\
\text { (individuals.ha }^{-1} \text { ) }\end{array}$ & $\begin{array}{l}\text { DAP inclusion } \\
\text { level }(\mathbf{c m})\end{array}$ & $\begin{array}{c}\text { Shannon- } \\
\text { Wiener } \\
\text { diversity index }\end{array}$ & Authors \\
\hline $\begin{array}{c}\text { Parque Estadual Vila } \\
\text { Velha - Ponta Grossa } \\
\text { (PR) }\end{array}$ & 20 & 10 & 2.48 & $\begin{array}{l}\text { Greiner et al. } \\
\qquad(2011)\end{array}$ \\
\hline $\begin{array}{l}\text { Departamento de Polícia } \\
\text { Federal - Curitiba (PR) }\end{array}$ & 118 & 10 & 3.12 & $\begin{array}{l}\text { Barreto et al. } \\
\quad(2014)\end{array}$ \\
\hline $\begin{array}{c}\text { Parque Municipal do } \\
\text { Barigüi - Curitiba (PR) }\end{array}$ & 120.64 & 10 & 3.14 & $\begin{array}{l}\text { Kozera et al. } \\
\qquad(2006)\end{array}$ \\
\hline $\begin{array}{l}\text { Faxinal do Salto - } \\
\text { Rebouças (PR) }\end{array}$ & 90 & 10 & 2.25 & $\begin{array}{l}\text { Watzlawick et al. } \\
\qquad(2011)\end{array}$ \\
\hline $\begin{array}{c}\text { Flona de Irati - Fernandes } \\
\text { Pinheiro (PR) }\end{array}$ & 4.8 & 10 & 3.57 & $\begin{array}{l}\text { Sawczuk et al. } \\
\quad \text { (2012) }\end{array}$ \\
\hline $\begin{array}{l}\text { Três Barras and } \\
\text { Canoinhas (SC) }\end{array}$ & 25 & - & 3.76 & $\begin{array}{l}\text { Siminski et al. } \\
\text { (2011) }\end{array}$ \\
\hline Caíva in Três Barras (SC) & 2 & 5 & 3.31 & $\begin{array}{l}\text { Siminski et al. } \\
\text { (2011) }\end{array}$ \\
\hline $\begin{array}{c}\text { Caíva in Major Vieira } \\
\text { (SC) }\end{array}$ & 78 & 5 & 2.74 & $\begin{array}{l}\text { Siminski et al. } \\
\qquad(2011)\end{array}$ \\
\hline
\end{tabular}

Note: $\mathrm{PR}=$ Paraná; $\mathrm{SC}=$ Santa Catarina

Ecological niche modeling was closely associated with bioclimatic variables in defining the suitability of the occurrence areas of Curitiba prismatica, but many factors were disregarded, as is the case of intra and interspecific competition. In the fragments conserved in Curitiba, as well as in the faxinal system, there is probably intense intraspecific competition, because of the high density and aggregation of the species (WATZLAWICK et al., 2011). Due to anthropogenic impacts and climate change, it is estimated that the Atlantic Forest will in the future be prone to homogenization of woody species (ZWIENER et al., 2017). Thus, efforts are needed for the conservation of Curitiba prismatica and other native species, aiming to minimize the reduction of their effective niches.

Areas with greater suitability have lower seed predation rates, and consequently higher germination rates (ODA et al., 2019). Therefore, considering the suitable areas, the endemism, and the anthropic pressure on the species, in situ conservation of all-natural populations should be carried out, prioritizing those with the highest degree of conservation. Ex situ conservation is also indicated, using the species in plantations for the recovery of degraded areas and integrated systems in regions with suitability, aiming at sustainable management.

This study generated relevant information to determine the suitability in the present and future areas, and provides important information for the conservation of Curitiba prismatica, and can also be used to support the recovery of degraded areas. Through the prediction, it was possible to observe the high endemism of the species in mixed ombrophilous forest areas. 


\section{CONCLUSIONS}

- As noted, the species has a restricted distribution to the regions of the states of Paraná and Santa Catarina, which are suitable to its occurrence.

- The models presented excellent AUC values in all projections.

- In the future, areas with high suitability will contract, and will remain restricted to the regions of the first and second plateau of Paraná and north of the state of Santa Catarina, which are the most suitable areas for commercial planting and in situ and ex situ conservation of the species.

\section{ACKNOWLEDGMENTS}

The present work was carried out with the support of the Coordenação de Aperfeiçoamento de Pessoal de Nível Superior - Brazil (CAPES), Financing Code 001.

\section{REFERENCES}

AGUiAR-MELO, C.; ZANELlA, C. M.; GOETZE, M.; PALMA-SILVA, C.; HIRSCH, L. D; NEVES, B.; COSTA, A. F.; BERED, F. Ecological niche modeling and a lack of phylogeographic structure in Vriesea incurvata suggest historically stable areas in the southern Atlantic Forest. American Journal of Botany, Lancaster, v. 106, n. 7, p. 971-983, 2019. doi: 10.1002/ajb2.1317

BARRETO, T. G.; CORTE, A. P. D.; MOGNON, F.; RODRIGUES, A. L.; SANQUETTA, C. R. Dinâmica da biomassa e do carbono em fragmento urbano de Floresta Ombrófila Mista. Enciclopédia Biosfera, Jandaia, v. 10, n. 18, p. 1300-1315, 2014.

BERGAMIN, R. S.; DEBASTIANI, V.; JONER, D. C.; LEMES, P.; GUIMARÃES, T.; LOYOLA, R. D.; MÜLLER, S. C. Loss of suitable climatic areas for Araucaria forests over time. Plant Ecology \& Diversity, Oxfordshire, v. 12, n. 2, p. 115-126, 2019. doi: 10.1080/17550874.2019.1618408

BRASIL. Flora do Brasil 2020 em construção. Jardim Botânico do Rio de Janeiro. Disponível em: $<$ http://floradobrasil.jbrj.gov.br/reflora/floradobrasil/FB10337>. Acesso em: 09 Jan. 2020.

CARVALHO, M. C.; GOMIDE, L. R.; ACERBI JÚNIOR, F. W.; TNG, D. Potential and future geographical distribution of Eremanthus erythropappus (DC.) MacLeish: a tree threatened by climate change. Floresta $\mathbf{e}$ Ambiente, Seropédica, v. 26, n. 3, p. 1-13, 2019. doi: 10.1590/2179-8087.045518

GREINER, C. M.; ACRA, L. A.; SELUSNIACK, M. A. Composição florística e fitossociológica do componente arbóreo de um remanescente de floresta ombrófila mista no parque estadual de Vila Velha, Ponta Grossa, Paraná. In: CARPANEZZI, O. T. B.; CAMPOS, J. B. Coletânea de Pesquisas do Parque Estadual de Vila Velha, Cerrado e Guartelá. Curitiba, ed. IAP, 2011. 374p.

HUTCHINSON, G. E. Concluding remarks. Cold Spring Harbor Symposia on Quantitative Biology, New York, v. 22, p. 415-427, 1957.

IBGE. Manual técnico da vegetação brasileira. Rio de Janeiro: Fundação Instituto Brasileiro de Geografia e Estatística, 2012. 271p.

IPCC. Climate Change 2007: Summary for policymakers. Contribution of working group I to the fourth assessment report of the Intergovernmental Panel on Climate Change.

KOZERA, K.; DITTRICH V. A. O.; SILVA, S. M. Fitossociologia do componente arbóreo de um fragmento de Floresta Ombrófila Mista Montana, Curitiba, PR, BR. Floresta, Curitiba, v. 36, n. 2, p. 225-237, 2006. doi: $10.5380 /$ rf.v36i2.6456

LORENZI, H. Árvores Brasileiras: manual de identificação e cultivo de plantas arbóreas nativas do Brasil. v. 2. Nova Odessa: Plantarum, 2014. 384p.

MAGURRAN, A. E. Medindo a diversidade biológica. Curitiba: Editora UFPR, 2011. 261p.

MAIA, V. A.; AGUIAR-CAMPOS, N.; SOUZA, C. R.; FAGUNDES, N. C. A.; SANTOS, A. B. M.; PAIS, A. J. R.; MOREL, J. D.; FARRAPO, C. L.; SANTOS, R. M. Temporal shifts on tree species niches: how do they affect species dynamics and community diversity? Plant Ecology, Dordrecht, v. 221, p. 25-39, 2019. doi: 10.1007/s11258-019-00988-z 
ODA, G. A. M.; SIQUEIRA, M. F.; PIRES, A. S.; PORTELA, R. C. Q. Micro-or macroscale? Which one best predicts the establishment of an endemic Atlantic Forest palm? Ecology and Evolution, Dordrecht, v. 9, p. 72847290, 2019. doi: 10.1002/ece3.5300

RIBEIRO, M.C.; METZGER, J.P.; MARTENSEN, A.C.; PONZONI, F.J.; HIROTA, M.M. The Brazilian Atlantic Forest: How much is left, and how is the remaining forest distributed? Implications for conservation. Biological Conservation, Essex, v. 142. p. 1141-1153, 2009. doi: 10.1016/j.biocon.2009.02.021

RODERJAN, C. V.; GALVÃO, F.; KUNIYOSHI, Y. S.; HATSCHBACH, G. As unidades fitogeográficas do Estado do Paraná. Ciência \& Ambiente, Santa Maria, v. 24, n. 1, p. 75-42, 2002.

SÁNCHEZ-TAPIA, A.; GARBIN, M. L.; SIQUEIRA, M. F.; GUIDONI-MARTINS, K. G.; SCARANO, F. R.; CARRIJO, T. T. Environmental and geographical space partitioning between core and peripheral Myrsine species (Primulaceae) of the Brazilian Atlantic Forest. Botanical Journal of the Linnean Society, London, v. 187, n. 4, p. 633-652, 2018. doi: 10.1093/botlinnean/boy034

SAWCZUK, A. R; FIGUEIREDO FILHO, A.; DIAS, A. N.; WATZLAWICK, L. F.; STEPKA, T. F. Alterações na estrutura e na diversidade florística no período 2002-2008 de uma Floresta Ombrófila Mista Montana do CentroSul do Paraná, Brasil. Floresta, Curitiba, v. 42, n. 1, p. 1-10, 2012. doi: 10.5380/rf.v42i1.26286

SILVA, M. A. F.; HIGUCHI, P.; SILVA, A. C. Impacto de mudanças climáticas sobre a distribuição geográfica potencial de Ilex paraguariensis. Rodriguésia, Rio de Janeiro, v. 69, n. 4, p. 2069-2079, 2018. doi: 10.1590/21757860201869437

SIMINSKI, A.; FANTINI, A. C.; GURIES, R. P.; RUSCHEL, A. R.; REIS, M. S. Secondary Forest Succession in the Mata Atlantica, Brazil: Floristic and Phytosociological Trends. ISRN Ecology, v. 2011, p. 1-19, 2011. doi: $10.5402 / 2011 / 759893$

THE PLANT LIST. The Plant List. Version 1.1. 2013. Disponível em: < http://www.theplantlist.org/>. Acesso em: 06 de fev. 2019.

URBANETZ, C.; OLIVEIRA, V. M.; RAIMUNDO, R. L. G. Padrão espacial, escala e síndromes de dispersão. 2003. Disponível em: Acesso em: < https://www2.ib.unicamp.br/profs/fsantos/ecocampo/ne211r3a2003.pdf $>$ Acesso em: 20 out. 2019.

WATZLAWICK, L. F.; ALBUQUERQUE, J. M.; REDIN, C. G.; LONGHI, R. V.; LONGHI, S. J. Estrutura, diversidade e distribuição espacial da vegetação arbórea na Floresta Ombrófila Mista em Sistema Faxinal, Rebouças (PR). Ambiência, Guarapuava, v. 7, p. 415-427, 2011.

ZWIENER, V. P.; LIRA-NORIEGA, A.; GRADY, C. J.; PADIAL, A. A.; VITULE, J. R. S. Climate change as a driver of biotic homogenization of woody plants in the Atlantic Forest. Global Ecology and Biogeography, Oxford, v. 27, n. 3, p. 298-309, 2017. doi: 10.1111/geb.12695 